\title{
PENGARUH PEMBIAYAAN BAGI HASIL TERHADAP PROFITABILITAS PT. BANK MEGA SYARIAH PERIODE 2008-2011
}

\author{
Oleh : \\ Imas Purnamasari \\ (Dosen Program Studi Pendidikan Akuntansi FPEB-UPI) \\ Widi Asih Noor Latifah \\ (Alumni Program Studi Pendidikan Akuntansi FPEB-UPI)
}

\begin{abstract}
Penelitian ini mengkaji tentang fenomena profitabilitas PT. Bank Mega Syariah yang secara rata-rata per-tahun cenderung mengalami penurunan dan nilai ROA yang masih belum memenuhi standar yang ditetapkan Bank Indonesia. Sementara total asset Bank Mega Syariah pada periode tersebut terus mengalami kenaikan sedangkan laba yang diperoleh mengalami fluktuasi serta mempengaruhi profitabilitas bank. Penelitian ini bertujuan untuk mengetahui apakah terdapat pengaruh antara tingkat pembiayaan bagi hasil terhadap profitabilitas PT. Bank Mega Syariah. Dalam penelitian ini, penulis menggunakan dua variabel, yaitu pembiayaan bagi hasil sebagai variabel independen serta profitabilitas sebagai variabel dependen yang dihitung dengan menggunakan Retum on Asset.

Penelitian ini menggunakan metode analisis deskriptif dan metode verifikatif. Untuk mengolah dan menganalisis data yang diperoleh serta membuat kesimpulan penelitian digunakan alat statistik uji linieritas, dan regresi linier sederhana. Data diperoleh melalui laporan keuangan publikasi Bank Indonesia per triwulan mulai dari periode Maret 2008 sampai dengan September 2011.

Berdasarkan hasil pengolahan data diperoleh persamaan regresi linier sederhana $Y=-1,72+1,89 X$. Persamaan tersebut menunjukkan bahwa pembiayaan bagi hasil memberikan pengaruh positif terhadap profitabilitas PT. Bank mega Syariah. Artinya, pada saat pembiayaan bagi hasil (variabel X) yang disalurkan mengalami kenaikan 1 unit, maka profitabilitas (variabel Yi) akan naik sebesar 1,89 unit dengan asumsi variabel lainnya konstan.
\end{abstract}

Kata Kunci: Pembiayaan Bagi Hasil, Profitabilitas, Bank Syaniah

\section{Pendahuluan}

Perkembangan perbankan syariah pada era reformasi ditandai dengan disetujuinya UndangUndang No.10 Tahun 1998. Dalam undang-undang tersebut diatur dengan rinci landasan hukum serta jenis-jenis usaha yang dapat dioperasikan dan diimplementasikan oleh bank syariah, juga memberikan arahan bagi bank-bank konvensional untuk membuka cabang syariah atau bahkan mengkonversi diri secara total menjadi bank syariah. Dari data statistik Bank Indonesia tahun 2010, terdapat 10 Bank umum Syariah. Tiga diantaranya merupakan bank umum syariah yang telah beroperasi tujuh tahun atau lebih yaitu Bank Muamalat Indonesia, Bank Syariah Mandiri dan Bank Mega Syariah. Sementara itu bank umum yang telah memiliki unit usaha syariah adalah 23 bank diantaranya merupakan bank besar seperti Bank Negara Indonesia (Persero) dan Bank Rakyat Indonesia (Persero).

Agar bank tidak mengalami kerugian, sangat penting bagi manajemen untuk menjaga keseimbangan antara profitability dan safety yang penekanannya berada pada pengaturan sumber dana yang diterima dengan aktiva produktif yang dikeluarkan oleh bank. Untuk meningkatkan profitabilitasnya, bank akan berusaha meningkatkan pengumpulan dana dari sumber dana yang tersedia disertai dengan upaya meningkatkan kualitas penyaluran aktiva produktif agar dapat menghasilkan tingkat keuntungan atau kinerja keuangan bank yang baik. Kinerja keuangan bank merupakan salah satu keberhasilan atas kesehatan suatu bank.

Penilaian terhadap kinerja suatu bank dapat dilakukan dengan melakukan analisis terhadap laporan keuangannya. Pengukuran tingkat kesehatan bank harus dilakukan oleh semua bank baik bank konvensional maupun bank syariah karena terkait dengan kepentingan semua pihak terkait, baik pemilik, pengelola (manajemen) bank, masyarakat pengguna jasa bank, Bank Indonesia selaku otoritas pengawasan bank, dan pihak lainnya. Informasi mengenai kondisi suatu bank dapat digunakan untuk mengevaluasi kinerja bank dalam menerapkan prinsip kehati-hatian, kepatuhan terhadap ketentuan ketentuan yang berlaku dan manajemen resiko.

Dikemukakan oleh Dwi Suwiknyo (2009:63) bahwa, "Cara untuk dapat menilai kinerja keuangan suatu perbankan dapat dilihat dengan menggunakan analisis rasio keuangan".Salah satu jenis rasio keuangan yang sering digunakan oleh perbankan adalah rasio profitabilitas. Dwi Suwiknyo (2010; 64) menjelaskan bahwa "Rasio prifitabilitas adalah rasio yang menunjukkan tingkat efektivitas yang dicapai melalui usaha operasional bank". Jadi, rasio ini mengukur efektifitas manajemen berdasarkan hasil pengembalian yang dihasilkan dari pinjaman dan investasi. 
Indikator yang biasa digunakan utnuk mengukur kinerja profitabilitas bank adalah ROA (Return on Assets) yaitu rasio yang menunjukkan kemampuan dari keseluruhan aktiva yang ada dan yang digunakan untuk menghasilkan keuntungan.

Suatu bank dikatakan sehat atau mempunyai kinerja keuangan yang sangat baik jika nilai ROA- nya melebihi standart yang telah ditentukan oleh Bank Indonesia yaitu diatas 1,25

Salah satu Bank Umum Syariah yang ada di Indonesia adalah Bank Syariah Mega Indonesia. Berikut merupakan data nilai Return On Assets (ROA) PT Bank Mega Syariah dari triwulan I tahun 2008 sampai dengan triwulan I tahun 2011

Tabel 1

Return on Assets PT. Bank Mega Syariah Periode 2008-2010

\begin{tabular}{|c|c|c|c|c|c|c|c|}
\hline No. & Periode & Triwulan & $\begin{array}{l}\text { Total } \\
\text { Aktiva }\end{array}$ & $\begin{array}{l}\text { Laba sblm } \\
\text { Pajak }\end{array}$ & ROA & $\begin{array}{l}\text { Rata- } \\
\text { rata }\end{array}$ & $\begin{array}{c}\text { Perkembangan } \\
(\%)\end{array}$ \\
\hline \multirow{4}{*}{1.} & \multirow{4}{*}{2008} & I & 2.112 .049 & 23.284 & 1,1 & \multirow{4}{*}{1,2} & . \\
\hline & & II & 2.183 .709 & 34.305 & 1,57 & & 42,73 \\
\hline & & III & 2.658 .546 & 36.103 & 1,36 & & $-13,38$ \\
\hline & & IV & 3.096 .201 & 23.717 & 0,77 & & $-43,38$ \\
\hline \multirow{4}{*}{2.} & \multirow{4}{*}{2009} & I & 3.321 .456 & 5.215 & 0,16 & \multirow{4}{*}{1,05} & $-79,22$ \\
\hline & & II & 3.642 .622 & 27.137 & 0,74 & & 362,50 \\
\hline & & III & 4.019 .737 & 56.455 & 1,40 & & 89,19 \\
\hline & & IV & 4.381 .991 & 83.785 & 1,91 & & 36,43 \\
\hline \multirow{4}{*}{3.} & \multirow{4}{*}{2010} & I & 4.365 .675 & 34.981 & 0,8 & \multirow{4}{*}{1,48} & $-58,12$ \\
\hline & & II & 4.474 .923 & 65.672 & 1,47 & & 83,75 \\
\hline & & III & 4.455 .914 & 82.414 & 1,85 & & 25,85 \\
\hline & & IV & 4.660 .762 & 84.352 & 1,81 & & $-2,16$ \\
\hline \multirow{3}{*}{4.} & & 1 & 4.295 .103 & 18.710 & 0,44 & \multirow{3}{*}{0,79} & $-75,69$ \\
\hline & 2011 & II & 4.487 .694 & 39.448 & 0,82 & & 86,36 \\
\hline & & III & 4.787 .695 & 53.393 & 1,15 & & 32,49 \\
\hline
\end{tabular}

Dari data di atas, diketahui bahwa total aktiva yang diperoleh PT Bank Mega Syariah terus mengalami peningkatan setiap triwulannya, sementara laba yang diperoleh cenderung berfluktuasi. Hal tersebut tentunya akan mempengaruhi terhadap besarnya profitabilitas yang didapatkan oleh bank. Nilai profitabilitas yang diperoleh PT. Bank Mega Syariah secara rata-rata per-tahun cenderung mengalami penurunan dengan nilai ROA yang sangat rendah. Profitabilitas tertinggi mencapai $1,91 \%$ dan terendah yaitu $0,16 \%$. Sedangkan menurut ketentuan Bank Indonesia, bank dikatakan sehat jika ROA-nya di atas 1,25\%. Sementara, total asset Bank Mega Syariah pada periode tersebut terus mengalami kenaikan rata-rata sebesar 10\% lebih. (laporan keuangan Bank Mega Syariah periode 2008-2011).

Hal tersebut menunjukan posisi bank pada tahun 2008 dan 2009 belum bisa memaksimalkan aktiva yang dimilikinya untuk menghasilkan profit. Aktiva yang digunakan untuk menghasilkan keuntungan adalah aktiva produktif. Salah satu aktiva produktif yang paling utama bagi perbankan syariah adalah pembiayaan. Menurut data statistik perbankan syariah BI tahun 2010, proporsi pembiayaan dari aktiva produktif selalu diatas $70 \%$, maka dapat dikatakan bahwa sumber terbesar keuntungan perbankan berasal dari pembiayaan. Pembiayaan merupakan aktiva yang paling produktif, sehingga sangat berpengaruh terhadap keuntungan yang kemudian akan berpengaruh terhadap profitabilitas.

Dalam perbankan syariah terdapat dua jenis pembiayaan utama yakni pembiayaan modal dan pembiayaan jual beli. Pembiayaan modal lazim juga disebut sebagai pembiayaan dengan skema bagihasil, dimana bank syariah memberikan pembiayaan untuk modal usaha nasabahnya, baik dalam bentuk mudharabah maupun musyarakah.

Pada praktiknya, pembiayaan pada bank syariah untuk saat ini tampak masih belum seimbang. Fakta menunjukkan bahwa pembiayaan syariah menggunakan skema murabahah atau jual beli menjadi lebih tinggi daripada pembiayaan lainnya. Padahal jiwa dari sistem operasional pembiayaan perbankan syariah adalah berdasarkan mudharabah atau musyarakah karena pada dasarnya sistem yang digunakan perbankan syariah adalah sistem bagi-hasil dan bagi risiko yang sebenarnya merupakan ciri khas bank syariah dan membedakannya dari bank konvensional ternyata penyalurannya masih kecil. Untuk lebih jelasnya, dapat dilihat pada tabel berikut:

Tabel 2

Perbandingan Jumlah Pembiayaan Bagi Hasil Dan Pembiayaan Mrabahah (Jual Beli) PT Bank Mega Syariah

\begin{tabular}{lll} 
Periode/Triwulan & $\begin{array}{l}\text { Pembiayaan } \\
\text { Bagi Hasil }\end{array}$ & $\begin{array}{l}\text { Pembiayaan } \\
\text { Jual } \\
\text { (Murabahah) }\end{array}$ \\
\hline Triwulan I/2008 & 135.141 & 1.468 .036 \\
Triwulan II/2008 & 147.875 & 1.391 .657 \\
Triwulan III/2008 & 145.669 & 1.650 .650 \\
Triwulan IV/2008 & 133.269 & 1.957 .787 \\
Triwulan I/2009 & 120.562 & 2.282 .695 \\
Triwulan II/2009 & 164.383 & 2.533 .339 \\
Triwulan III/2009 & 182.801 & 2.726 .437 \\
Triwulan IV/2009 & 193.926 & 2.870 .847 \\
Triwulan I/2010 & 183.578 & 2.996 .443 \\
Triwulan II/2010 & 173.541 & 3.076 .856 \\
Triwulan III/2010 & 158.410 & 3.112 .822 \\
Triwulan IV/2010 & 140.095 & 2.937 .755 \\
Triwulan I/2011 & 131.791 & 2.744 .768 \\
Triwulan II/2011 & 135.195 & 2.792 .084 \\
Triwulan III/2011 & 139.147 & 3.029 .180 \\
Jumlah & 2.285 .383 & 34.711 .663
\end{tabular}

Sumber: Laporan Keuangan Publikasi Bank Indonesia (Bank Mega Syariah Periode 2008-2011). 
Berdasarkan tabel di atas, terlihat bahwa jumlah pembiayaan murabahah yang disalurkan oleh bank lebih besar dibandingkan jumlah pembiayaan bagi hasil. Perkembangan jumlah pembiayaan bagi hasil dari tahun 2008-2011 mengalami perkembangan rata-rata $0,84 \%$ setiap triwulannya, dan terjadi penurunan yang cukup besar pada tahun pada tahun pada 2008 dan 2010. Meskipun demikian, baik pembiayaan bagi hasil maupun pembiayaan murabahah merupakan komponen aktiva yang akan memberikan kontribusi laba bagi bank. Semakin besar pembiayaan yang disalurkan, maka diharapkan tingkat pengembaliannya akan lancar dan mengahasilkan keuntungan yang besar agar dapat membantu meningkatkan profit bank itu sendiri.

Penelitian ini mengacu pada penelitian sebelumnya yang dilakukan oleh Rosliana mengenai pengaruh pembiayaan murabahah terhadap Return On Assets (ROA). Perbedaannya terletak pada objek penelitian yaitu pada penelitian sebelumnya, yang menjadi variabel dependent penelitiannya adalah pembiayaan murabahah sedangkan yang menjadi variabel independent pada penelitian ini adalah pembiayaan bagi hasil. Kedua jenis pembiayaan ini merupakan sumber pendapatan bagi Bank Syariah karena menghasilkan keuntungan dan risiko yang berbeda. Pembiayaan bagi hasil yang memiliki ketidakpastian yang lebih tinggi dibandingkan dengan pembiayaan murabahah. Namun, merupakan jiwa utama dari perbankan syariah karena pembargian keuntunnya berdasar atas prinsip syariah.

Berdasarkan masalah yang telah dikemukakan, maka dirumuskan masalahnya:

a. Bagaimana Perkembangan Pembiayaan Bagi Hasil pada PT. Bank Mega Syariah periode 2008-2011.

b. Bagaimana Perkembangan Profitabilitas pada PT. Bank Mega Syariah periode 20082011.

c. Bagaimana Pengaruh Pembiayaan Bagi Hasil terhadap profitabilitas PT. Bank Mega Syariah periode 2008-2011.

\section{Landasan Teori}

Perpaduan antara praktik-praktik perbankan konvensional dengan prinsip-prinsip dasar transaksi ekonomi Islam telah mampu melahirkan produk perbankan syariah yang saat ini terus tumbuh berkembang sangat luas dan lebih lengkap.

Bank syariah memenerapkan setiap transaksi pada suatu aturan perjanjian berdasar hukum Islam antara bank dengan pihak lain untuk penyimpanan dan atau pembiayaan kegiatan usaha atau kegiatan lainnya yang dinyatakan sesuai dengan syariah antara lain :
a. Pembiayaan berdasar prinsip jual beli (murabahah) ;
b. Pembiayaan berdasar prinsip bagi hasil (mudharabah dan ,musyarakah);
c. Pembiayaan barang modal berdasar prinsip sewa murni tanpa pilihan (ijarah)
d. Pembiayaan dengan akad pelengkap

Dari keempat jenis pembiayaan tersebut, penyaluran dana bank syariah sebagai upaya memperoleh keuntungan terdiri dari tiga bentuk pembiayaan utama yaitu pembiayaan berdasarkan prinsip bagi hasil, prinsip jual-beli, dan prinsip sewamenyewa.

Perkembangan mengenai kecilnya pembiayaan bagi hasil terutama pembiayaan dengan akad mudharabah di Indonesia mendapat perhatian khusus dari berbagai kalangan, mengingat bahwa asas dasar perbankan syariah adalah bagi hasil. Pembiayaan bagi hasil terdiri dari pembiayaan dengan akad mudharabah atau sering disebut dengan istilah pembiayaan mudharabah dan pembiayaan dengan akad musyarakah atau pembiayaan musyarakah.

Pembiayaan mudharabah adalah akad kerjasama usaha antara Bank sebagai pemilik dana (shahibul maal) dan nasabah sebagai pengelola dana (mudharib) untuk melakukan kegiatan usaha dengan nisbah pembagian hasil (keuntungan atau kerugian) menurut kesepakatan dimuka. Sedangkan Pembiayaan musyarakah adalah akad kerjasama yang terjadi diantara para pemilaik modal (mitra musyarakah) untuk menggabungkan modal dan melakukan usaha secara bersama dalam suatu kemitraan dengan nisbah pembagian hasil sesuai dengan kesepakatan, sedangkan kerugian ditanggung secara proporsional sesuai dengan kontribusi modal.

Keuntungan yang diperoleh dari pembiayaan bagi hasil didasarkan atas bagi hasil yang ditentukan pada saat akad dan disesuaikan dengan bentuk akad yang digunakan (mudharabah atau musyarakah). Keuntungan yang dibagi hasilkan didapat dari selisih pendapatan dan modal yang dikeluarkan untuk investasi yang dilakukan. Jika besar keuntungan telah diketahui secara pasti, maka langkah selanjutnya adalah melakukan pembagian sesuai porsi yang telah disepakati bersama. Jika pada saat akad ditentukan porsi pembagian keuntungan antara bank dan pihak nasabah adalah $40: 60$, maka $40 \%$ dari keuntungan yang diperoleh akan menjadi profit bagi pihak bank.

Dalam sistem perbankan syariah dengan prinsip bagi hasil sebenarnya bukan hanya pembagian keuntungan, tetapi juga kerugian atau dikenal dengan pembagian untung-rugi sesuai dengan porsi yang telah disepakati. Kerugian yang ditanggung nasabah dilihat dari faktor yang menyebabkan kerugian tersebut. Apabila kerugian disebabkan atas kelalaian nasabah, maka nasabah harus mengganti kerugian tersebut, tapi apabila kerugian disebabkan oleh factor bencana alam, maka nasabah tidak perlu menanggung kerugian tersebut.

pembiayaan merupakan penyediaan dana yang dilakukan oleh bank untuk memenuhi kebtuhan nasabahnya sebagai pinjaman produktif dan akan memberikan bagian bagi pemberi pinjaman sebesar bunga/ nisbah bagi hasil yang telah disepakati bersama. Muhammad (2002:19) menyatakan bahwa hasil dari penyaluran pembiayaan, diharapkan bank dapat meneruskan 
dan mengembangkan usahanya agar tetap bertahan dan meluas jaringan usahanya. Kemudian dijelaskan kembali (Muhammad, 2002:21) bahwa:

Peningkatan usaha berarti peningkatan profit. Apabila keuntungan ini secara kumulatif dikembangkan lagi dalam arti kata dikembalikan lagi ke dalam struktur permodalan, maka peningkatan akan berlangsung terus menerus".

Dari penjelasan di atas kegiatan utama bank syariah adalah menyalurkan pembiayaan karena akan menghasilkan keuntungan sehingga bank syariah tetap dapat bertahan dan mengembangkan usahanya. Namun, mengingat pembiayaan bagi hasil memiliki risiko yang lebih tinggi dibandingkan pembiayaan lainnya, maka bank harus dapat mengelola pembiayaan bagi hasil secara optimal. Jika bank tidak berhati-hati dalam menyalurkan pembiayaan maka bank akan mengalami penurunan profit bahkan akan mengalami kerugian. Seperti yang diungkapkan oleh C. Harinowo ( 2004)

"Perkembangan kredit terlalu cepat dapat memunculkan problem baru, yaitu munculnya kualitas kredit yang buruk yang akhirnya bisa mengarah kepada permasalahan yang terjadi selama krisis yang lalu. Oleh karena keluruhan hal ini akan mempengaruhi tingkat profitabilitas perbankan".

Pembiayaan bagi hasil sebagai salah satu bentuk penyaluran dana (pembiayaan) merupakan asset bank syariah yang dapat menghasilkan keuntungan jika dikelola dengan sangat baik. Pengelolaan pembiayaan sangat penting untuk mengoptimalkan profit, jika pengelolaannya kurang baik maka akan berpengaruh terhadap ROA bank. Pembiayaan bagi hasil yang besar akan mempengaruhi jumlah aktiva jika dapat dikelola dengan baik maka bank akan memperoleh profit dari sistem bagi hasil pembiayaan yang diberikan sehingga dapat meningkatkan ROA bank yang kemudian akan meningkatkan profitabilitas bank. Berdasarkan kerangka berpikir di atas, hubungan variabel dalam penelitian ini dapat digambarkan sebagai berikut:

Variabel $X \longrightarrow$ Variabel $Y$

\section{Gambar 1}

Hubungan Variabel

$X=$ Pembiayaan Bagi hasil
$Y=$ Profitabilitas

Hipotesis yang akan diuji dalam penelitian ini adalalah: "Pembiayaan Bagi Hasil berpengaruh positif terhadap Profitabilitas PT. Bank Mega Syariah"

\section{Metode Penelitian \\ Metode yang digunakan dalam penelitian ini adalah metode deskriptif dan verifikatif. \\ Dalam penelitian ini terdapat dua variabel yang akan dikaji yaitu variabel bebas $(X)$ dan satu variabel terikat $(Y)$ yang saling berkaitan antara lain; \\ Pembiayaan Bagi Hasil sebagai variabel bebas $X$ (Variabel Independen, \\ Profitabilitas (ROA) sebagai variabel terikat $Y$ (Variabel Dependen). \\ Untuk lebih jelasnya, maka variabel dalam penelitian ini lebih dirinci dalam tabel operasionalisasi berikut:}

Tabel 3

Operasionalisasi Variabel

\begin{tabular}{ll} 
VARIABEL & \multicolumn{1}{c}{ KONSEP VARIABEL } \\
Pembiayaan & Salah satu jenis pembiayaan untuk \\
Bagi hasil & usaha yang melibatkan dua pihak \\
$(X)$ & atau lebih dimana bank syariah \\
& membiayai I memberikan modal \\
& usaha nasabahnya, baik dalam \\
& bentuk mudharabah maupun \\
musyarakah & \\
Profitabilitas & Kemampuan perusahaan untuk \\
& menghasilkan laba selama periode \\
& tertentu.
\end{tabular}

Sumber data yang digunakan oleh peneliti adalah sumber data sekumder. Data sekunder didapat melalui berbagai sumber yaitu literatur buku, artikel, laporan keuangan publikasi Bank Indonesia berupa neraca dan laporan laba rugi PT. Bank Mega Syariah dari triwulan I tahun 2008-triwulan III tahun 2011 yang diperoleh dari situs internet yaitu pada website Babnk Indonesia dan laporan tahunan PT. Bank Mega Syariah.

Setelah semua dokumen yang berkaitan dengan data yang diperlukan dalam penelitian terkumpul, data tersebut kemudian dipelajari dan diolah sehingga lebih mudah untuk dianalisis agar dapat menjawab tujuan-tujuan penelitian.

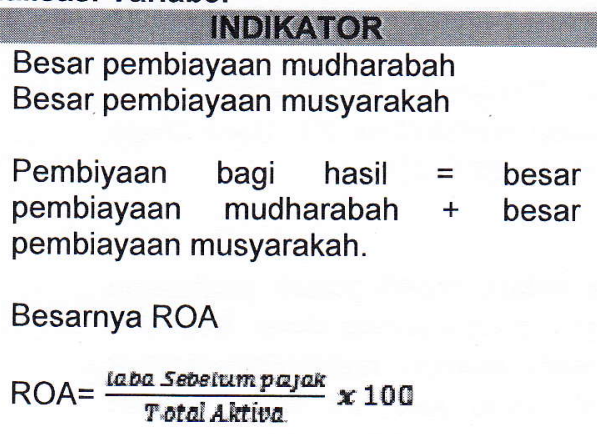

Rasio SKALA

Rasio

Mengumpulkan data laporan keuangan tahunan dari periode 2008-2011 untuk kemudian mengelompokkan data mengenai jumlah pembiayaan bagi hasil yang diberikan PT. Bank Mega Syariah yang menjadi sampel penelitian. Menghitung besaran Return On Assets (ROA) bank dengan membandingkan total aktiva yang terdapat dalam neraca dan total laba sebelum pajak yang terdapat dalam laporan rugi/laba bank pada periode 2006-2010.

Menguji sebaran data dengan menggunakan uji normalitas. Menghitung koefisien korelasi dan koefisien determinasi secara manual dengan menggunakan program SPSS. Menarik kesimpulan berdasarkan hasil penelitian mengenai seberapa 
besar pengaruh pembiayaan bagi hasil terhadap profitabilitas.

\section{Hasil Penelitian dan Pembahasan}

Analisis Regresi linier sederdana digunakan untuk mengetahui derajat hubungan antara variabel bebas (independent) dengan variabel terikat (dependent). Dalam penelitian ini, digunakan bentuk perhitungan secara manual.

Dari hasil perhitungan, didapat nilai konstanta - 1,72 berarti bahwa tingkat profitabilitas ketika pembiayaan bagi hasil bernilai 0 , dan memiliki koeffisien regresi sebesar 1,89. Artinya, pada saat pembiayaan bagi hasil (variabel $X$ ) yang disalurkan mengalami kenaikan 1 unit, maka profitabilitas (variabel Yi) akan naik sebesar 1,89 unit dengan asumsi variabel lainnya konstan.

Berdasarkan hasil analisis statistik data yang dilakukan, menunjukkan bahwa penelitian ini telah membuktikan hipotesis yang menyatakan bahwa pembiayaan bagi hasil berpengaruh positif terhadap profitabilitas, sesuai dengan yang dikemukakan Mahmoedin (2002: 20) bahwa salah satu faktor yang mempengaruhi profitabilitas adalah kualitas kredit/ pembiayaan yang disalurkan beserta pengembaliannya. Kemudian menurut Kasmir (2007:71), "Kegiatan Bank sebagai lembaga keuangan, pemberian kredit merupakan kegiatan utamanya. Besar kredit yang disalurkan akan menentukan keuntungan bank".

Dari analisis data, dapat diketahui pengaruh jumlah pembiayaan bagi hasil terhadap profitabilitas adalah positif (searah). Dari hasil perhitungan diperoleh nilai persamaaan $Y=-1,72+1,89 X$. Konstanta $-1,72$ berarti bahwa tingkat profitabilitas ketika pembiayaan bagi hasil bernilai 0 , dan memiliki koeffisien regresi sebesar 1,89. Artinya, pada saat pembiayaan bagi hasil (variabel $X$ ) yang disalurkan mengalami kenaikan 1 unit, maka profitabilitas (variabel Yi) akan naik sebesar 1,89 unit dengan asumsi variabel lainnya konstan. Tanda positif pada variabel independent menunjukkan bahwa variabel dependen yaitu jumlah pembiayaan bagi hasil berpengaruh positif terhadap profitabilitas PT. Bank Mega Syariah. Hal itu berarti bahwa pada setiap kenaikan jumlah pembiayaan bagi hasil akan diikuti dengan kenaikan profitabilitas, atau pada saat jumlah pembiayaan meningkat, profitabilitas yang dicapai oleh PT. Bank Mega Syariah akan ikut meningkat. Sebaliknya, pada saat jumlah pembiayaan yang disalurkan semakin kecil perolehan profitabilitas PT. Bank Mega syariah semakin meningkat. Hal tersebut dapat dilihat pada pengolahan data sebelumnya bahwa ada beberapa kuartal yang menunjukkan bahwa pembiayaan bagi hasil mengalami peningkatan pada triwulan I dan II tahun 2008 dan setiap periode pada tahun 2009 sementara profitabilitas mengalami penurunan. Hal tersebut menunjukkan bahwa peningkatan pembiayaan bagi hasil memiliki pengaruh yang sangat kecil terhadap profitabilitas. Hal tersebut dimungkinkan karena faktor manajemen risiko yang masih belum baik sehingga terjadi ketidaksesuaian antara peningkatan pembiayaan bagi hasil yang disalurkan dengan profitabilitas. Sesuai dengan disebutkan oleh Suhardjono (dalam Hana hasanah, 2009:36) bahwa 'Risiko kerugian akibat pemberian kredit yang tidak lancar tentunya akan berpengaruh terhadap pendapatan dan keuntungan yang diterima oleh bank.'

Apabila melihat hasil penelitian yang telah dilakukan sebelumnya mengenai pengaruh pembiayaan murabahah terhadap Return On Assets (ROA) kemudian membandingkannya dengan hasil penelitian tentang pengaruh pembiayaan bagi hasil terhadap profitabilitas PT. Bank Mega Syariah, maka dapat disimpulkan bahwa terdapat pengaruh yang sama, yaitu positif antara pembiayaan terhadap profitabilitas.

\section{Simpulan dan Saran}

Berdasarkan hasil analisis statistik data yang dilakukan, menunjukkan bahwa jumlah pembiayaan bagi hasil memiliki pengaruh positif terhadap profitabilitas. Hal itu berarti bahwa pada kenaikan jumlah pembiayaan bagi hasil akan diikuti dengan kenaikan profitabilitas, atau pada saat jumlah pembiayaan menurun maka profitabilitas pun menurun.

Dari hasil analisis data dan pembahasan yang telah diuraikan, perkembangan pembiayaan dengan presentase yang sangat kecil. Mengingat bahwa pembiayaan bagi hasil merupakan ciri khas produk pembiayaan bank syariah maka pihak bank harus bisa menjadikan pembiayaan bagi hasil sebagai produk unggulan bank sesuai dengan prinsip utamanya yaitu bagi hasil dengan terus meningkatkan porsi pembiayaan bagi hasil dengan mepertimbangkan kualitas pengelolaan dan risiko pembiayaan bagi hasil..

Hasil analisis data mengenai profitabilitas yang menunjukkan peningkatan hampir disetiap periodenya juga masih harus terus ditingkatkan. Salah satu caranya adalah dengan melakukan pembiayaan yang sangat baik dan efisien dengan memperketat prosedur kelayakan pembiayaan khususnya pembiayaan bagi hasil agar tingkat pengembaliannya lancar sehingga dapat menambah kontribusi yang besar dalam meningkatkan laba bank. Karena laba yang baik akan mnentukan baik tidaknya profitabilitas suatu bank.

Kenaikan pembiayaan yang diimbangi dengan kenaikan profitabilitas dapat dijadikan acuan bagi bank dalam menyalurkan pembiayaan bagi hasil ataupun pembiayaan lainnya. Pihak bank dapat merencanakan atau menentukan berapa porsi pembiayaan yang disalurkan setiap periodenya dengan mempertimbangkanp beberapa hal yang telah dibahas sebelumnya.

Penelitian terhadap faktor lain yang mempengaruhi profitabilitas misalnya; tingkat NPF (Non Performing Finance), kualitas pembiayaan bagi hasil atau pun pembiayaan lainnya (murabahah, ishtishna, ijarah), sistem pengendalian intern bank dalam menyalurkan pembiayaan, pendapatan dari pembiayaan, porsi bagi hasil, tingkat pengembalian aktiva produktif dari 
pembiayaan, Loan to Deposit Ratio (LDR), Capital Adequaty Ratio (CAR) dan manajemen pengalokasian dana dalam aktiva likuid. Selain itu, peneliti selanjutnya juga dapat mengganti variabel dependent (variabel terikat) dengan objek lainnya, misalkan laba bersih, likuiditas, rasio lain yang dilakukan untuk menganalisis laporan keuangan perbankan syariah.

\section{DAFTAR PUSTAKA}

Alwi.S (1989). Alat-alat Analisis dalam Perusahaan. Yogyakarta: Liberty

Anshori,A.G (2007). Perbankan Syariah di Indonesia. Yogyakarta: UGM.

.(2008). Penerapan Prinsip Syariah Dalam Lembaga Keuangan, Lembaga Pembiayaan dan Perusahaan Pembiayaan. Yogyakarta: Pustaka Pelajar.

Agnes Sawir. ( 2005). Analisis Kinerja Keuangan \& Perencanaan Keuangan Perusahaan. Jakarta: Gramedia Pusaka Utama.

Antonio,M.S. (2001). Bank Syariah dari Teori ke Praktik. Jakarta: Gema Insani.

Arim .(2004). Pelatihan perbankan Syariah. Bandung: Universitas pendidikan Indonesia.

Ascarya.(2004). Mencari Solusi Pembiayaan Bagi Hasil Perbankan Syariah. Jakarta: Lembaga Pengembangan Perbankan Indonesia (LPII) Direktorat Bidang Syariah.

Chapra. \& Habib Ahmed. (2008). Corporate Governance (Lembaga keuangan Syariah). Jakarta: Bumi Aksara

Duane B. Graddy, Austin H. Spancer. (1990). Managing Commercial Banks. Community, regional, and global.

Dwi priyatno. (2008). Mandiri belajar SPSS. Jakarta: MediaKom.

Dwi Suwiknyo. (2010). Analisis Laporan Keuangan Perbankan Syariah. Yogyakarta: Pustaka Pelajar

Kashmir. (2008). Dasar-Dasar Perbankan. Jakarta: PT Raja Grafindo Persada. (2007). Analisis laporan Keuangan. Jakarta: Rajawali

Paul D. Kimmel, Ph.D., Donald E. Kieso, Ph.D., Jerry J. Weygandt, Ph.D. Accounting Principles. John Wiley

Karim,A (2004). Bank Islam Analisis Fiqih dan Keuangan. Jakarta: PT Raja Grafindo Persada

Lewis \& Algoud. (2001). Perbankan Syariah (Prinsip, Praktik, Prospek). Jakarta: Serambi

Lukman Dendawijaya. (2003). Manajemen

Perbankan. Jakarta: Ghalia Indonesia.

Mahmoedin. (2002). Etika Bisnis Perbankan. Jakarta: Pustaka Sinar Harapan

Muhammad. (2004). Teknik Perhitungan Bagi Hasil dan Profit Margin pada Bank Syariah. Yogyakarta: UII Pers

Munawir. (2002). Analisis Laporan Keuangan. Yogyakarta:Liberty
Nazir,M. (2003). Metode Penelitian. Jakarta: Ghalia Indonesia

Riduwan. (2008). Dasar-Dasar Statistika. Bandung: CV Alfabeta.

Rivai, V, dkk. (2007). Bank and Financial Institution Management (Conventional and Sharia System). Jakarta: Rajawali Pers.

Sastradipoera. (2004). Bank dan Perbankan Manajemen. Bandung: Kappa-Sigma

Siamat,D. (2004). Manajemen dan Lembaga Keuangan Syariah. Jakarta: Lembaga Penerbit fakultas Ekonomi Universitas Indonesia

Soemarso S.R (2005). Akuntansi Suatu Pengantar. Jakarta: Salemba Empat.

Sofyan S. Et all. (2004). Perbankan Syariah Akuntansi. Jakarta: LPFE Usakti.

Sudjana. (2004). Statistika II (untuk ekonomi dan niaga). Bandung : Tarsito.

Sugiyono. (2004). Metode Penelitian Bisnis. Bandung: CV Alfabeta.

Sjahdeini, SR (1999). Perbankan Is/am (dan Kedudukannya dalam tata Hukum Indonesia). Jakarta: Grafiti.

Yaya, R dkk. (2009). Akuntansi Perbankan Syariah (Teori dan Praktik Kontemporer).Jakarta: Salemba Empat.

Zulkifli Sunarto. (2003). Panduan Praktis Transaksi perbankan Syariah (Edisi Mahasiswa). Jakarta : Zikrul Hakim. 